\title{
Scanning electron microscopy of mosquitoes Part IV. The egg surface structure of 3 species of Aedes from Japan
}

\author{
Kikuo MATSUO* \\ Department of Medical Zoology, Kyoto Prefectural University of \\ Medicine, Kamikyo-ku, Kyoto 602, Japan \\ (Received: January 15, 1975)
}

\begin{abstract}
The egg surface structure of 3 species of Aedes from Japan is described and illustrated with the aid of a scanning electron microscope. The characters of the outer chorion for separating the eggs of 7 species of Aedes and 1 species of Armigeres from Japan, 3 species of the present report and 5 species of the 1 st report of this series, are presented in Table 1.
\end{abstract}

The scanning electron microscope produces fine quasi-three dimensional micrographs of the surface structure of mosquitoes. The author used the instrument to observe the surface structure of mosquito eggs of 25 species from Japan, Taiwan, Malaysia and Indonesia $(1972,1974 \mathrm{a}, \mathrm{b})$. The 1st report of this series (1972) described the egg surface structure of 4 species of Aedes and 1 species of Armigeres from Japan and also presented a key to the eggs of these species based on the outer chorion on the upper (ventral) surface.

In this 4th report, the upper surface structures of the eggs of Aedes (Stegomyia) flavopictus, A. (Ochlerotatus) excrucians and $A$. (O.) hexodontus from Japan are described and illustrated. The characters of the outer chorion for separating the eggs of these 3 species and the 5 species from Japan of the 1 st report of this series are presented on Table 1.

\section{MATERIALS AND METHODS}

The specimens examined included both eggs produced by wild females and eggs by females developed, in a insectarium, from wild larvae. The methods follow those used

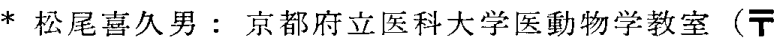
602 京都市上京区河原町広小路）
}

in the 2nd report of this series (1974a): nomenclature is also the same. Measurements are given in microns, and the mean and standard errors appear in parentheses after the range of variation. $\mathrm{L}$ indicates the lengih and $\mathrm{W}$ the diameter at the widest point. The results are from observations of the upper (ventral) surface of the eggs.

\section{RESULTS}

\section{Aedes (Stegomyia) flavopictus Yamada, 1921}

Japanese name: Yamada-shimaka

Figs. 1-4.

Size : L $500-550 \quad(516 \pm 6)$; W $140-180$ $(156 \pm 7)$.

Chorion: Reticulation composed of a pattern of roughly pentagonal, hexagonal or sometimes transversely elongated rhombic cells at $500 \times$ magnification; 1 , sometimes 2, large papillae, roughly hemispherical, present at center of each cell; at high magnification $(1000 \times)$ surface of papilla appearing rough; small papillae forming a row parallel to ridge, often confluent with large papilla and ridge; papillae absent on inner chorion.

Remarks: The egg is similar to that of A. (S.) albopictus from Japan and Taiwan, $A$. (S.) aegypti from Taiwan and Malaysia, 
Table 1 Characters of outer chorion on upper (ventral) surface used for differentiating the eggs of 7 species of Aedes and 1 species of Armigeres from Japan.

\begin{tabular}{|c|c|c|c|c|c|c|c|c|}
\hline Diagnostic characters & 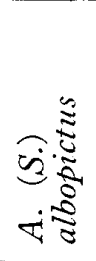 & 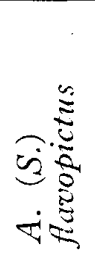 & $\begin{array}{l}\widehat{E} \cdot \overrightarrow{8} \\
\dot{8}\end{array}$ & 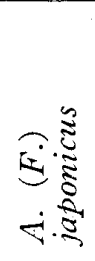 & 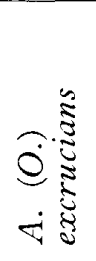 & 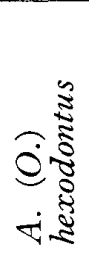 & 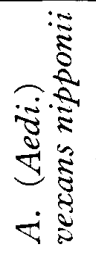 & 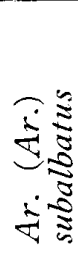 \\
\hline $\begin{array}{l}\text { Reticulation composed of pattern of polygo- } \\
\text { nal and rhombic cells }\end{array}$ & $+^{*}$ & + & + & + & + & + & - & + \\
\hline $\begin{array}{l}\text { Reticulation composed of pattern of antero- } \\
\text { posteriorly elongated cells }\end{array}$ & - & - & - & - & - & - & + & - \\
\hline $\begin{array}{l}\text { Conspicuous ridge of reticulation encompass- } \\
\text { ing from } 6 \text { to } 12 \text { cells }\end{array}$ & - & - & - & - & + & - & - & - \\
\hline $\begin{array}{l}\text { With } 1 \text {, sometimes } 2 \text {, large hemispherical } \\
\text { papillae at center of each cell }\end{array}$ & + & + & - & - & - & - & - & - \\
\hline $\begin{array}{l}\text { With } 1 \text { large flat toped papilla at center of } \\
\text { each cell }\end{array}$ & - & - & - & - & + & + & - & - \\
\hline $\begin{array}{l}\text { With } 2 \text { to } 4 \text { large flat toped papillae in each } \\
\text { cell }\end{array}$ & - & - & - & + & - & - & - & - \\
\hline $\begin{array}{l}\text { With } 1 \text { papilla having lines radiated toward } \\
\text { ridge in each cell }\end{array}$ & - & - & - & - & - & - & - & + \\
\hline $\begin{array}{l}\text { With only small papillae of more or less } \\
\text { uniform size in each cell }\end{array}$ & - & - & + & - & - & - & - & - \\
\hline
\end{tabular}

$*+=$ Character present $;-=$ Character absent.

and $A$. (S.) pseudalbopictus and $A$. (S.) alcasidi from Taiwan described by Matsuo et al. $(1972,1974 \mathrm{a}, \mathrm{b})$, but shorter than that of A. (S.) aegypti. The egg is identical with that of the same species from Japan described by Moriya et al. (1973).

Source of eggs: From adults collected at Katagihara, Kyoto, Japan in August 1973.

\section{Aedes (Ochlerotatus) excrucians (Walker, 1856) \\ Japanese name: Akan-yabuka}

Figs. 5-9.

Size: L $750-830(778 \pm 14)$; W $220-250$ (234士5).

Chorion: Reticulation composed of a pattern of roughly polygonal cells at $500 \times$ magnification, on some parts of chorion, conspicuous ridge of reticulation encompassing from 6 to 12 cells; reticulation of inner chorion forms same pattern as outer chorion; one large papilla, irregular in shape, present in each cell, top of papilla appearing somewhat flat; small papillae, irregular in shape, sometimes present between large papilla and ridge; papillae absent on inner chorion.
Remarks: The egg is similar to that of $A$. (O.) hexodontus described in this paper, but the conspicuous ridge of reticulation encompasses from 6 to 12 cells. Kalpage et al. (1968) and Moriya et al. (1973) presented the micrographs of the same species with the aid of a phase contrast microscope and scanning electron microscope, respectively. However, those micrographs gave only a poor impression.

Sources of eggs: From adults developed, in a insectarium, from larvae collected at Shiretoko-goko, Hokkaido, Japan and from adults collected at the same place in June 1974.

\section{Aedes (Ochlerotatus) hexodontus Dyer, 1916 \\ Japanese name; Kita-yabuka}

Figs. 10-12.

Size: L 830 (not available); W 230 (not available)

Chorion: Very similar to that of $A$. (O.) excrucians.

Remarks: The egg is very similar to that of A. (O.) excrucians described in this paper, 


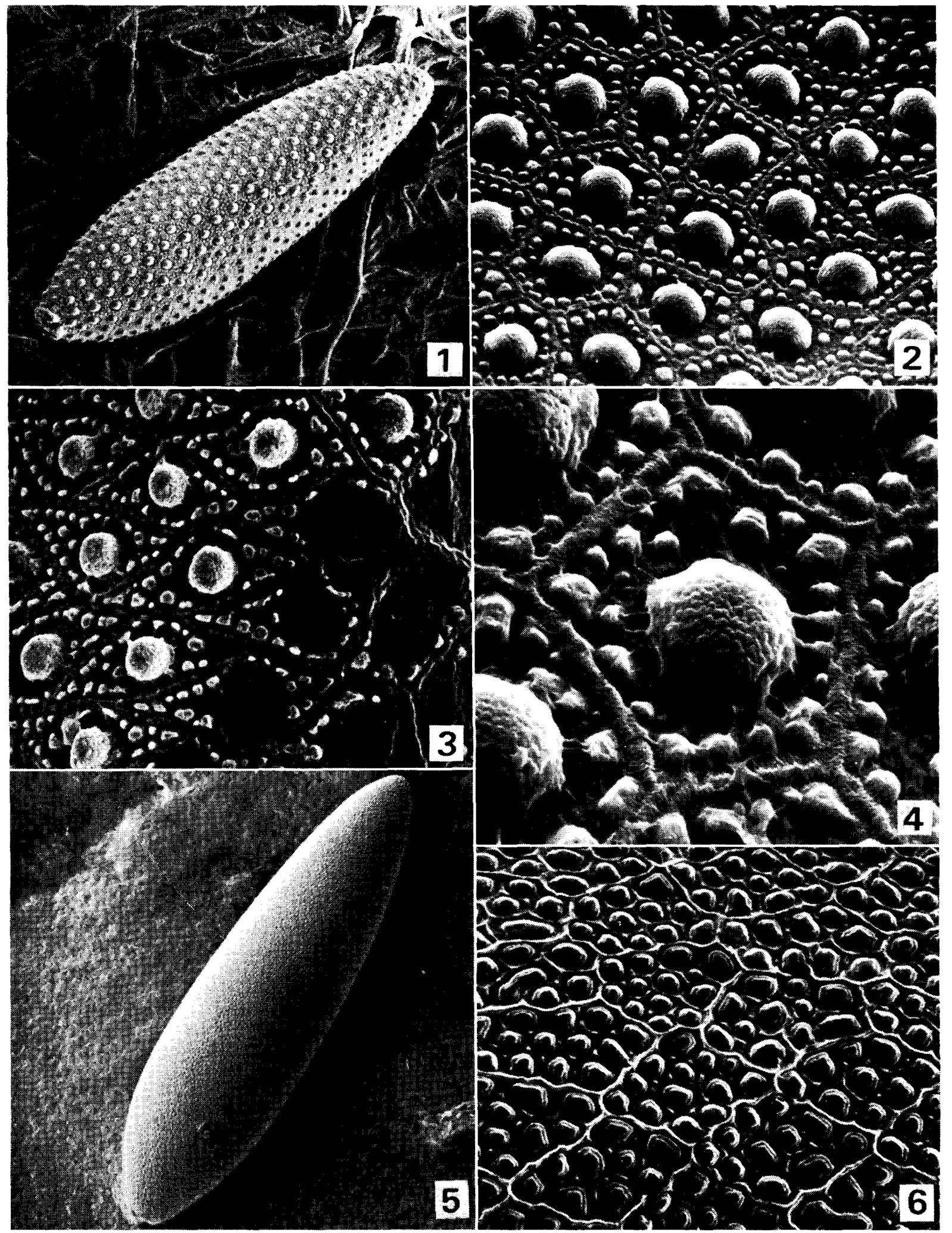

Figs. 1-4. A. (S.) flavopictus: (1) $\times 130,(2) \times 1,000,(3) \times 890$, a part where some papillae are flayed, (4) $\times 2,790$. Fig. 5-6. A. (O.) excrucians : $(5) \times 90,(6) \times 810$. 


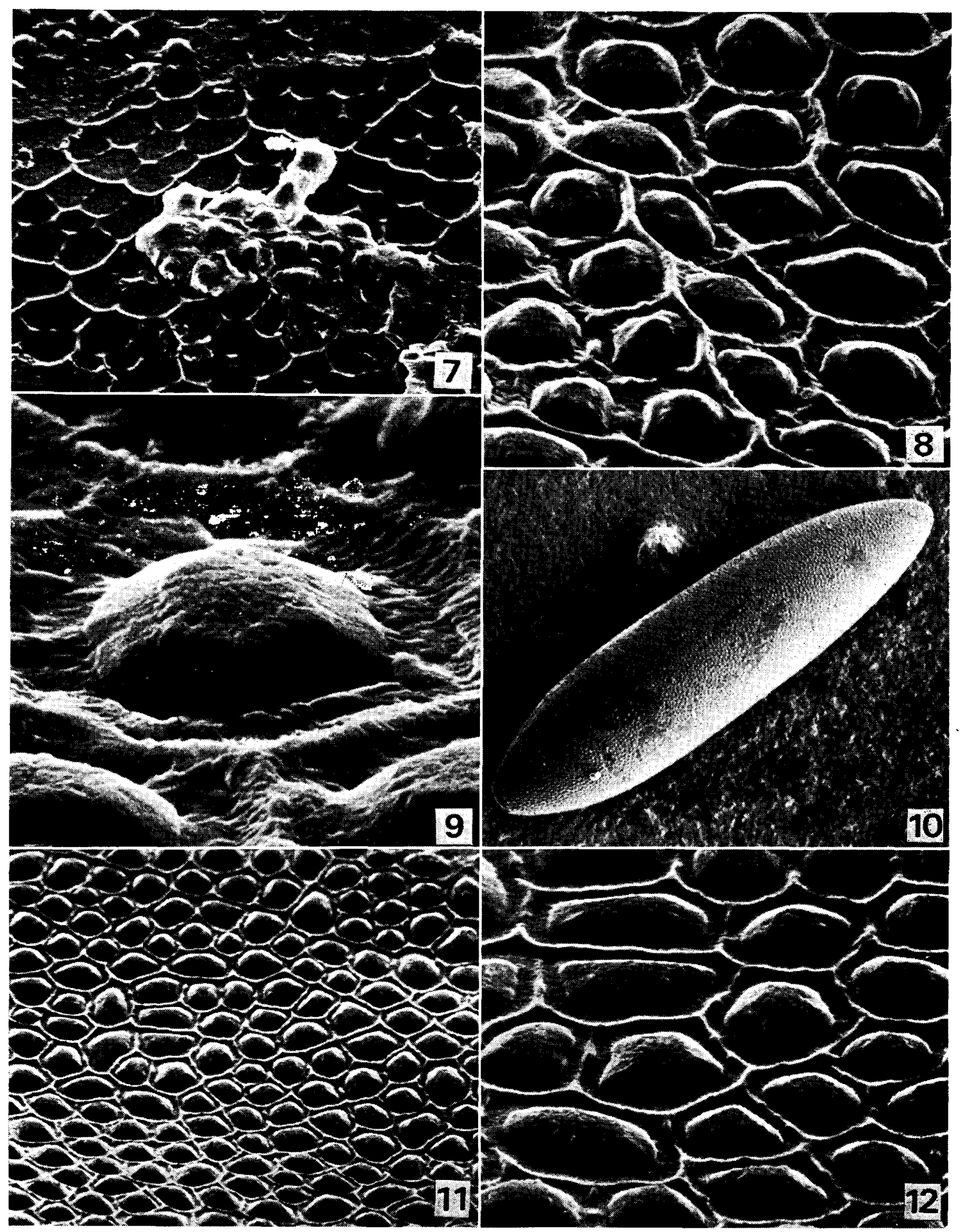

Figs. 7-9. A. (O.) excrucians: (7) $\times 920$, a part where outer chorion is flayed, (8) $\times 2,710$, (9) $\times 9,590$. Figs. 10-12. A. (O.) hexodontus : $(10) \times 90$, (11) $\times 780,(12) \times 2,750$. 
but conspicuous ridge of reticulation encompassing some cells can not be seen. The egg is not similar to that of the same species, as viewed with the aid of a phase contrast microscope, described by Kalpage et al. (1968). The closely related species, A. (O.) hexodontus and A. (O.) punctor, are so variable and difficult to separate that it will be necessary to carry out taxonomic experiments.

Sources of eggs: From adults collected at Shiretoko-goko and Sapporo, Hokkaido, Japan in June 1974.

\section{ACKNOWLEDGEMENT}

The author is grateful to Dr. S. Ito, Division of Public Health, Osaka Prefectural Institute of Public Health, for her help with the egg collections.

\section{REFERENCES}

Kalpage, K. S. and R. Brust (1968) : Mosquitoes of Manitoba. I. Descriptions and a key to Aedes eggs (Diptera: Culicidae). Can. J. Zool., $46: 699-718$.

Matsuo, K., Y. Yoshida and I. Kunou (1972): Scanning electron microscopy of mosquitoes.
I. The egg surface of five species of Aedes and Armigeres subalbatus. J. Kyoto Pref. Univ. Med., 81 (7) : 358-363.

Matsuo, K., Y. Yoshida and J. C. Lien (1974a) : Scanning electron microscopy of mosquitoes. II. The egg surface structure of 13 species of Aedes from Taiwan. J. Med. Ent., $11(2): 179-$ 188.

Matsuo, K., J. C. Lien and Y. Yoshida (1974b) : Scanning electron microscopy of mosquitoes. III. The egg surface structure of 5 species from Taiwan and 2 species from Indonesia. Formosan Med. Assoc., 73(8): 437-444.

Moriya, K., T. Yabe and F. Harada (1973): Chorionic markings of some Aedine mosquitoes in Japan. I. Preliminary observations by a scanning electron microscope and a reflected lighting microscope. Jap. J. Sanit. Zool., 24(1): 47-55 (in Japanese).

\section{摘 要}

\section{蚊の走查電子顕微鏡的研究 第 4 報} 日本産ヤブカ 3 種の沺表面像

日本産ヤマダシマカ，アカンヤブカ，キタヤブカの卵 表面を走査電子顥微鏡によって観察し，その形態を記述 した。そして既報種を含め日本産ヤブカ属 7 種, クロヤ ブカ属 1 種計 8 種について即表面像の異同を表記した。 